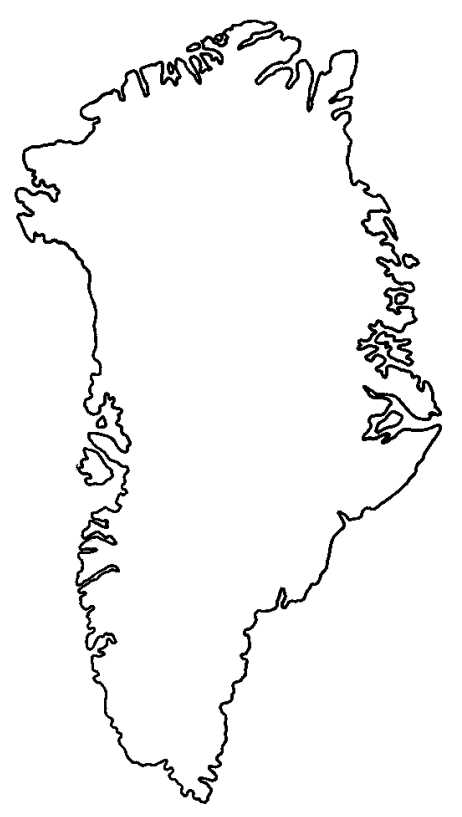

\title{
Notes on Lower Palaeozoic flysch trace fossils from Hall Land and Peary Land, North Greenland
}

\author{
Ronald K. Pickerill, John M. Hurst and \\ Finn Surlyk
}

\begin{abstract}
Seven ìchnospecies are recorded from the Cambrian to Silurian turbidite succession of North Greenland. Two specimens are of particular importance as they provide new data on the palaeoenvironmental and stratigraphic range of their contained traces. Protopaleodictyon sp. is recorded for the first time from the Cambrian. The occurrence of Rhizocorallium sp. in deep basinal turbidites extends its occurrence in such environments back to the Ordovician and emphasises that caution must be exercised when utilizing the trace as an environmental indicator.
\end{abstract}

R. K. P., Department of Geology, University of New Brunswick, P. O. Box 4400, Fredericton, New Brunswick, Canada E3B 5 A3.

J. M. H. \& F. S., Grønlands Geologiske Undersøgelse, Øster Voldgade 10, DK-1350 København K, Danmark.

Lower Palaeozoic flysch sequences in North Greenland were examined during 1979 with a view to identifying their contained ichnofauna. Due to the small number of available collections containing trace fossils, the lack of better-preserved and/or morphologically variable material and the unsatisfactory taxonomic status of many of the forms, the identifications have been restricted essentially to ichnogeneric level. In spite of the restricted material, two of the specimens warrant additional comment, as they provide new data on the palaeoenvironmental and stratigraphic range (respectively) of their contained traces.

\section{Ichnofauna, stratigraphy and location}

The following ichnofaunas, which were derived from the northern tip of Hall Land and the northern part of Peary Land (fig. 1), have been identified:

1) GGU collection 230278: Helminthopsis sp., Gordia sp., Planolites sp. From a variegated, thin-bedded, muddy turbidite wedge within the lower to middle part of the turbidite sequence constituting the Polkorridoren Group of north Peary Land (locality 1 on fig. 1). Cambrian age (Hurst \& Surlyk, 1980; Surlyk et al., 1980; Soper et al., 1980). 


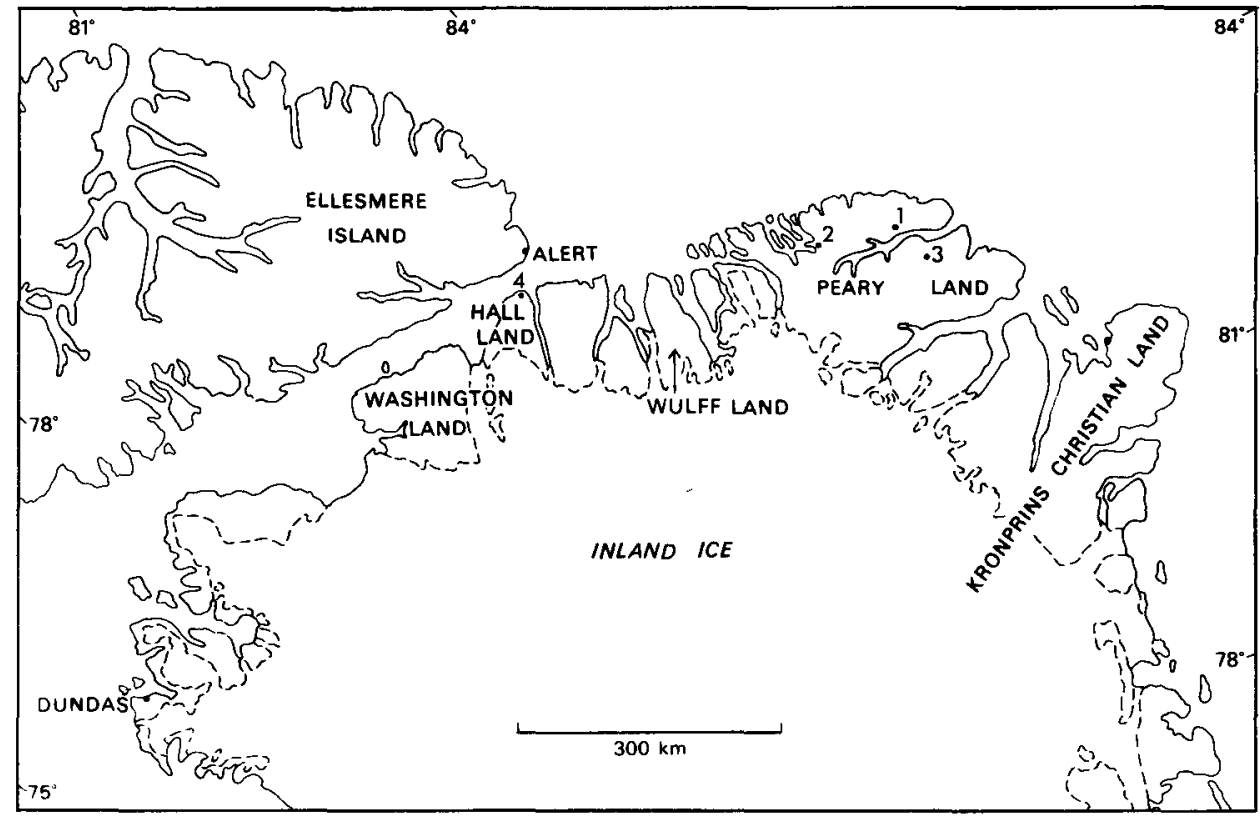

Fig. 1. Simplified geographical map of North Greenland showing the location of Hall Land and Peary Land. Locality numbers 1 to 4 referred to in text.

2) GGU collection 230279: Helminthopsis sp., Gordia sp., Protopaleodictyon sp., an unnamed horseshoe burrow. From the same unit as GGU collection 230278 (locality 1 on fig. 1).

3) GGU collection 230120: Rhizocorallium sp. From a sequence of thin-bedded silty turbidites, cherts and mudstones in north Peary Land, referred to by Dawes \& Soper (1979) as formation B (locality 2 on fig. 1). Ordovician age (Surlyk et al., 1980).

4) GGU collection 232306: Planolites sp. From the Silurian turbidites of Peary Land (locality 3 on fig. 1).

5) GGU collection 230195: Cochlichnus anguineus, Hitchcock, 1858, Planolites sp., an unnamed horseshoe burrow. From the Silurian turbidites of northern Hall Land (locality 4 on fig. 1).

6) GGU collection 230197: Planolites sp., Scolicia sp. From the Silurian turbidites of northern Hall Land (locality 4 on fig. 1).

\section{Ichnogenus Rhizocorallium Zenker, 1836}

\section{Rhizocorallium sp.}

Fig. 2a, b

Description. A gently curved protrusive U-shaped burrow at least $120 \mathrm{~mm}$ in length and 25 $\mathrm{mm}$ in width. The burrow contains closely spaced and distinctive spreite, evident as a series of alternating ridges and grooves, and is parallel to bedding. The external tube-shaped 

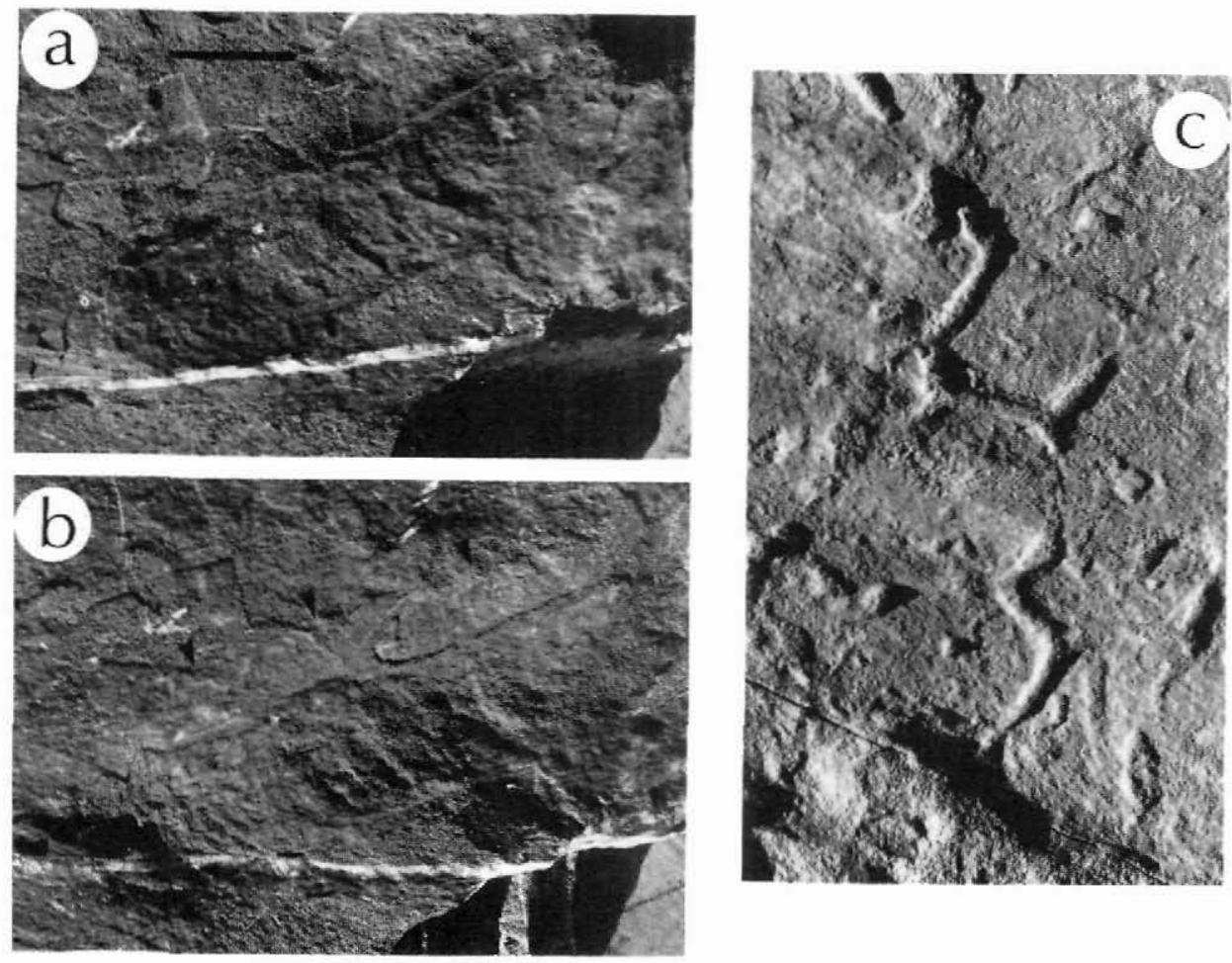

Fig. 2. a, b, Rhizocorallium sp. from the Ordovician turbidites of north Peary Land. a illustrates the spreite and $\mathrm{b}$ was taken using low angle light and illustrates the poorly preserved marginal tube, the edges of which are marked by arrowheads. Bar scale $=1 \mathrm{~cm}$. MGUH 15.263 from GGU 230120. c, Protopaleodictyon sp. from the Cambrian Polkorridoren Group turbidites of north Peary Land, $\times 1.5$. MGUH 15.264 from GGU 230279. Specimens are deposited in the type collection of the Geological Museum, Copenhagen.

burrow is poorly preserved but, where discernible, is $7 \mathrm{~mm}$ in width. The ratio of the width of the marginal tube to that of the spreite approximates to $1: 3.5$, which is close to the value given by Häntzschel (1960) as characteristic of Rhizocorallium.

Discussion. In view of the generally poor preservation, particularly of the marginal tubes, the specimen is only identified at ichnogeneric level. Nevertheless, the presence of these marginal tubes together with the given size dimensions distinguish the trace from the morphologically similar traces Scolicia spp., Muensteria spp. and Zoophycos insignis. The trace resembles $R$. irregulare Mayer, 1954, in that the burrow is horizontal, long and sinuous, but differs from it by having narrower tubes (see Fürsich, 1974).

Rhizocorallium has been recorded from neritic rocks of Cambrian-Tertiary age and is commonly regarded as being a characteristic shallow-water indicator (Chamberlain, 1978; Seilacher, 1978). Indeed, many authors have interpreted horizontal Rhizocorallium more specifically as shoreface indicators (see Basan \& Scott, 1979). Little regard, however, has 
been given to deep-water records in rocks particularly of Mesozoic and Tertiary age. Hayward (1976), for example, records Rhizocorallium in Miocene submarine canyon walls from New Zealand, Crimes (1977) in Eocene middle fan flysch sediments from northern Spain and Ksiaźkiewicz (1977) from both proximal and distal flysch in the Mesozoic of the Polish Carpathians. One of us (RKP) has also observed Rhizocorallium in delta front sediments and associated turbidites in the Carboniferous near Skipton, northern England. The example noted here now extends the known deep-water occurrences of Rhizocorallium back to the Ordovician. It seems likely, therefore, that the producing organism(s) (? crustaceans and/or annelids) was able to inhabit a variety of environments and that caution must be exercised when utilizing the trace as a specific palaeobathymetric indicator.

\section{Ichnogenus Protopaleodictyon Ksiąźkiewicz, 1970 Protopaleodictyon sp.}

Fig. 2c

Description. The base of the specimen consists essentially of a network of intersecting Helminthopsis burrows. Where undisturbed, however, horizontal tunnel systems with a wide first order meander upon which is superimposed second order sine-shaped undulations with distinct appendages may be discerned. The burrow system consists of tiny threads, each 2 $\mathrm{mm}$ in width and smooth throughout their length. The graphoglyptid burrows are apparently uniramous but because of incomplete and poor preservation this observation remains tentative.

Discussion. The incompleteness and poor preservation of the specimens prevents ichnospecific identification. In addition, there is still no agreement as to which characters constitute a distinctive ichnospecies of Protopaleodictyon. Seilacher (1977) utilized the number of branches/undulations and Ksiąźkiewicz (1977) employed the regularity and spacing of the first order meanders and the size and thickness of the strings. Nevertheless, it is clear that the trace can be assigned to Protopaleodictyon, a distinctive flysch graphoglyptid trace fossil.

The ichnogenus has commonly been regarded as Carboniferous - Tertiary in age (Häntzschel, 1975), though more recently Pickerill (1980) has recorded it from Ordovician flysch strata in eastern Canada. Its occurrence in the tubidites of the Polkorridoren Group now extends its observed stratigraphic range well back into the Cambrian.

\section{References}

Basan, P. B. \& Scott, R. W. 1979: Morphology of Rhizocorallium and associated traces from the Lower Cretaceous Purgatoire Formation, Colorado. Paleogeogr., Palaeoclimatol., Palaeoecol. 28, 5-23.

Chamberlain, C. K. 1978: Recognition of trace fossils in cores. In Basan, P. B. (edit.). Trace Fossil Concepts. Soc. Econ. Paleontol. Mineral., Short Course 5, 125-183.

Crimes, T. P. 1977: Trace fossils of an Eocene deep-sea sand fan. In Crimes, T. P. \& Harper, J. C. (edit.) Trace fossils 2. Geol. J. Spec. Issue 9, 71-90. Liverpool: Seel House Press.

Dawes, P. R. \& Soper, N. J. 1979: Structural and stratigraphic framework of the North Greenland fold belt in Johannes V. Jensen Land, Peary Land. Rapp. Grønlands geol. Unders. 93, 1-40.

Fürsich, F. T. 1974: Ichnogenus Rhizocorallium. Paläont. Z. 48, 16-29.

Häntzschel, W. 1960: Spreitenbauten (Zoophycos Massal.) im Septarienton Nordwest-Deutschlands. Mitt. geol. Staatsinst. Hamburg 29, 95-100. 
Häntzschel, W. 1975: Trace fossils and problematica. In Teichert, C. (edit.) Treatise on Invertebrate Paleontology W. Miscellanea, Suppl. 1, 3-269, Kansas U.P.

Hayward, B. W. 1976: Lower Miocene bathyal and submarine canyon ichnocoenoses from Northland, New Zealand. Lethaia 9, 149-162.

Hurst, J. M. \& Surlyk, F. 1980: Notes on the Lower Palaeozoic clastic sediments of Peary Land, North Greenland. Rapp. Grønlands geol. Unders. 99, 73-78.

Ksią̧́kiewicz, M. 1977: Trace fossils in the flysch of the Polish Carpathians. Palaeontologia Polonica 36, 1-208.

Pickerill, R. K. 1980: Phanerozoic flysch trace fossil diversity - observations based on an Ordovician flysch ichnofauna from the Aroostook - Matapedia Carbonate Belt of northern New Brunswick. Can. J. Earth Sci. 17, 1259-1270.

Seilacher, A. 1977: Pattern analysis of Paleodictyon and related trace fossils. In Crimes, T. P. \& Harper, J. C. (edit.) Trace fossils 2. Geol. J. Spec. Issue 9, 289-334. Liverpool: Seel House Press.

Seilacher, A. 1978: Use of trace fossils for recognizing depositional environments. In Basan, P. B. (edit.) Trace Fossil Concepts. Soc. Econ. Paleontol. Mineral., Short Course 5, 185-201.

Soper. N. J., Higgins, A. K. \& Friderichsen, J. D. 1980: The North Greenland fold belt in eastern Johannes V. Jensen Land. Rapp. Grønlands geol. Unders. 99, 89-98.

Surlyk, F., Hurst, J. M. \& Bjerreskov, M. 1980: First age-diagnostic fossils from the central part of the North Greenland foldbelt. Nature 286, 800-803. 